\title{
O espectador em pleno voo: as experiências do iNERTE
}

\section{Resumo}

O texto trata dos experimentos realizados pelo iNERTE - Instável Núcleo de Estudos de Recepção Teatral, criado em 2004, no Departamento de Artes Cênicas da Universidade de São Paulo. Calcado em investigações práticas e teóricas, o grupo busca viabilizar encontros cênicos que se organizam como estudos de recepção e efeito estético no teatro. Nos encontros promovidos pelo iNERTE, os participantes são convidados a observarem a si mesmos enquanto observam uma cena teatral, e a debaterem aspectos da relação entre teatro e sociedade, sob a perspectiva do ato do espectador.

Palavras-chaves: Espectador; Inerte; Recepção Teatral; Teatro

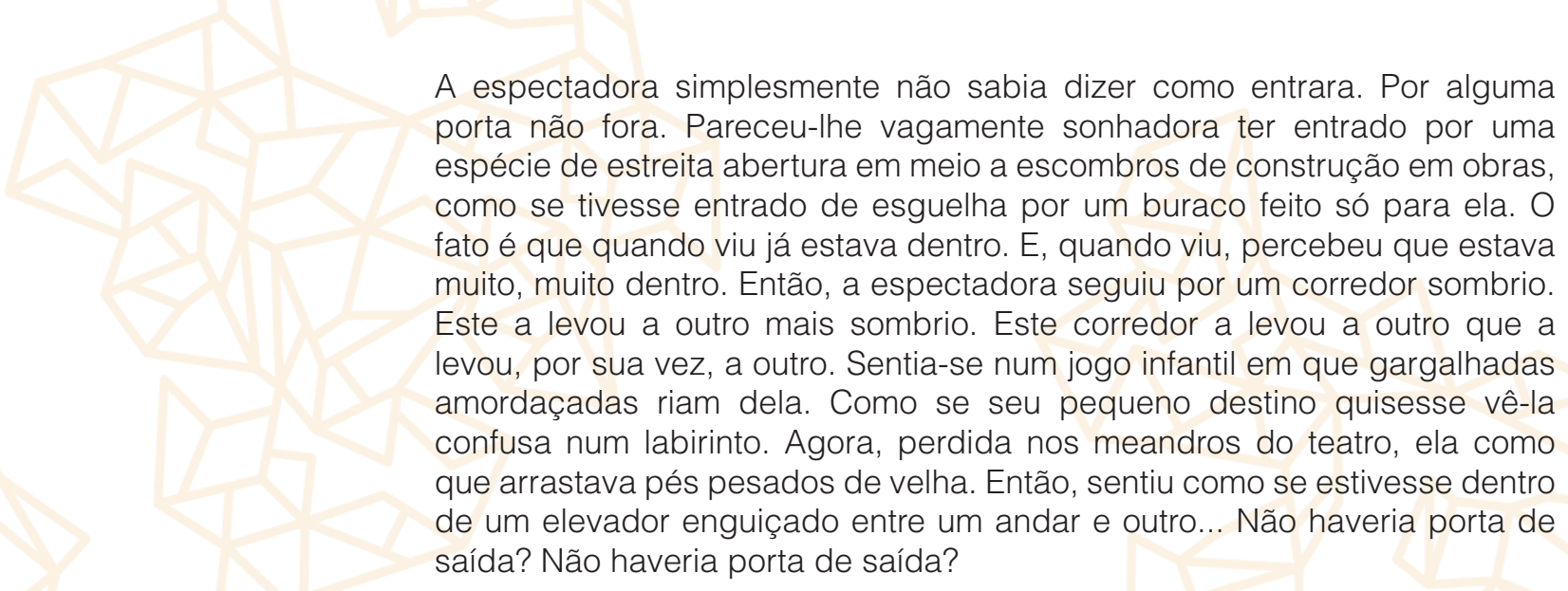

Barqueiro (personagem dos encontros cênicos do iNERTE)².

\section{A evidenciação dos processos internos do espectador}

O poeta Paulo Leminski, em texto que reflete sobre a trajetória histórica da composição poética, observa que antigamente o encontro com uma poesia se dava de maneira fácil, havia algumas certezas que o leitor podia desfrutar: "Poesia era aquela caixinha de bombons chamada soneto, um pedaço bem cortado de frases enfeitadas, que emitia sempre o mesmo plim, como um canário na gaiola ou uma caixinha de música" (LEMINSKI, 2011, p. 134). Mais adiante, no mesmo texto, ao se referir às alte-

\footnotetext{
1 Atriz e dramaturga. Doutora em Letras pela USP, autora do livro Veto ao modernismo no teatro brasileiro. São Paulo: Hucitec, 2010.

2 Inspirado em texto de Clarice Lispector (1994).
} 
rações propostas pelos artistas modernos, a partir dos anos de 1920, na cidade de São Paulo, Leminski sugere que, "em lugar do verbo agradar, passaram a conjugar o verbo agredir" (LEMINSKI, 2011, p. 135). A literatura, que era uma certeza e uma tranquilidade, desde então, se transformou em um problema.

A mesma falta de tranquilidade, de normas e de pistas facilitadoras de que fala Leminski acerca da literatura, podemos perceber diante da cena teatral desde a modernidade: desafiadora, inquietante, provocativa. "Aí começa a inevitável pergunta: isto é arte? Não, senhoras e senhores, a arte é que é isto. Qualquer isto. Um isto problemático, reflexivo, que é necessário interrogar e decifrar” (BRITO, 2005, p. 75). A cena teatral constitui-se, desde então, como "um isto problemático", sem receitas ou manual de instruções. O espectador não possui mapas nem bússolas que Ihe indiquem um caminho livre de perigos. Não há garantias de que a viagem se destina a um porto seguro. Não há um sentido único, definido previamente, que ele precisa encontrar na obra. A proposição artística faz-se ela própria uma interrogação sobre si mesma.

Desde as modificações operadas pela vanguarda histórica do início do século $X X$, o teatro evidencia a sua condição provocativa e questionadora, assumindo-se como algo que pode produzir perguntas e inquietações, mas que não se propõe a oferecer respostas. Desde então, o espectador está convidado a se colocar como decifrador de uma obra que possui como principal objeto de análise o próprio fazer teatral, a precipitação de seu processo e a explicitação de suas perguntas. $\mathrm{O}$ assumir da teatralidade presente nas produções cênicas faz-se também como assunção do ato produtivo do espectador. A teatralidade assumida carrega consigo também indícios da necessidade do encontro para a concretização da obra, deixando evidente que a atuação do espectador se faz incontornável para a efetivação do fato estético. O objeto artístico anseia pelo ato do espectador, por sua atuação pessoal e intransferível. Das fricções provenientes desse encontro, o objeto faz-se obra de arte.

A composição da cena atual segue propondo-se para além da cena propriamente constituída, segue instigando atos peculiares de recepção, gerando efeitos singulares, fazendo com que o próprio modo de percepção do espectador seja compreendido como um ato performativo. O olhar torna-se produtor de sentido e evidencia os rastros dos processos de elaboração desses mesmos sentidos. Colocar o espectador em ato produtivo e, além disso, fazê-lo perceber os meandros da própria leitura é o que denominamos aqui de observar o "espectador em pleno voo". 
No ano de 2004, dispostos a investigar aspectos do efeito estético provocado pela cena teatral recente e a desvendar como atua o espectador diante da profusão de significantes oferecidos pelas diversas proposições artísticas, fundamos o iNERTE Instável Núcleo de Estudos de Recepção Teatral. ${ }^{3}$ Calcado em investigações práticas e teóricas, o grupo realiza encontros cênicos que se organizam como estudos de recepção e efeito da obra de arte, convidando os participantes a se debruçarem sobre o ato do espectador no evento teatral, estimulando a análise do fazer artístico e as suas possibilidades de interferência na vida social.

A cena que o iNERTE se propõe a descortinar é aquela que surge do embate entre espectador e objeto artístico. A ideia central é pesquisar o processo criativo do espectador teatral, buscando enunciar, a partir do estudo de teóricos da recepção e de procedimentos artísticos propostos em eventos coletivos, aspectos desse modo de produção. De maneira a tornar reconhecíveis as instâncias dessa construção poética e a evidenciar os elementos que sustentam a noção de uma arte do espectador. A pesquisa do grupo procura recolher vestígios estéticos e históricos de como esse espectador, que se percebe atualmente em uma espécie de nó autorreflexivo, pois se vê provocado a observar a si mesmo enquanto observa a cena, analisa os seus processos internos ao mesmo tempo que realiza o próprio ato produtivo, a partir das proposições artísticas que lhe são oferecidas.

\title{
A angústia ante o que será descortinado
}

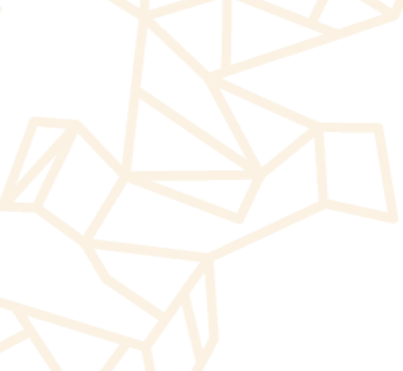

\begin{abstract}
O que esperamos quando nos vemos diante dos três sinais, ou da cortina que se levanta, que não seja esse curto momento de angústia, que se esvai rapidamente, mas que se faz sempre presente. Jacques Lacan
\end{abstract}

Eu li que a angústia é a vertigem da liberdade. Clarice Lispector

Além da pesquisa teórica sobre recepção e efeito estético no teatro, o grupo organiza experimentos práticos centrados em encontros cênicos acerca do ato do espectador. Uma personagem, nomeada Verônica, se coloca como na plateia de uma sala de teatro, ante um espetáculo prestes a começar:

\footnotetext{
3 Desde sua criação, o iNERTE contou com os seguintes pesquisadores: Flávio Desgranges, Marcelo Soler, Luciana Magiolo, Aline Ferraz, Gustavo Idelbrando, Suzana Schmidt Viganó, Ana Chiesa Yokoyama, Thaís Rangel e Giuliana Simões.
} 
Verônica - O teatro me deixa assim, inquieta. Parece que eu preciso ansiar por algo, lembrar de algo. Será que eu não posso simplesmente ficar aqui, sentada, tranquila com a situação? Prefiro o cinema, é mais confortável, adoro as poltronas das salas de exibição.

As cenas são organizadas de modo a evidenciar traços de uma poética do espectador, em que estudos teóricos acerca da recepção estética e passagens memoriais dos integrantes do grupo são estruturados como escritas cênicas. Além da apresentação das cenas, propostas de instalação artística, de improvisação e de debates performativos são feitas aos participantes do encontro. O objetivo central é colocar o espectador em condição de perceber a si mesmo, observar seus processos internos, mantendo-se atento ao próprio modo de recepção que engendra enquanto assiste às cenas. De maneira que cada participante possa refletir acerca dos meandros da atuação do espectador atualmente, a partir do modo de relacionar-se com o acontecimento em curso. O espaço do debate se abre como arena coletiva de produção de sentidos e troca de conhecimentos acerca da temática em questão.

Os encontros organizados pelo iNERTE estão calcados em três âmbitos que envolvem a relação do espectador com a obra teatral: a) o da criação, buscando estruturar um discurso cênico calcado em estética teatral provocativa, que estimule a atuação do espectador-participante do encontro; b) o da recepção, propondo uma cena que se apresenta como aula-espetáculo, abordando aspectos teóricos da recepção estética, organizados enquanto narrativa teatral, colocando em questão o papel do espectador no evento; e c) o da mediação, propondo instalações artísticas, improvisações teatrais e debates performativos em que os participantes são convidados a refletir e a se manifestarem acerca da posição de espectador e da "função" da arte teatral em nossos dias.

A cena ficcional proposta pelo grupo traz à tona a experiência de uma espectadora que, ante o descortinar de um acontecimento teatral, se depara com a angústia suscitada pelo desconhecido, o que está prestes a ser revelado. A trajetória dessa personagem é apresentada a partir da rememoração de cenas de sua existência, e de momentos vividos, ansiados ou ainda imaginados de sua relação com o teatro. Assim, como ressaltamos anteriormente, a cena que o iNERTE se propõe a descortinar e analisar é aquela que surge, inadvertidamente, do encontro entre espectador e objeto artístico.

Verônica - Estou ouvindo sons vindos lá de trás. Como podem se expor assim esses atores? Eles não sabem ao certo quem estará na plateia. Ainda bem que eu vim só para assistir. O que mesmo? E se eu não entender nada? Detesto me sentir burra. Detesto o que desconheço. E agora esse silêncio? Enorme. Será grande o suficiente para calar o indesejável? Hoje acordei com vontade de não ser, só queria parar de pensar, sentir menos e poder me livrar de mim. 
O texto aparece como um roteiro de ações, uma espécie de material propositor para o encontro entre o grupo e os espectadores. A expectativa e a angústia ante um espetáculo que está prestes a começar é o mote da dramaturgia. Tudo que surge nesse momento advém do imaginário da espectadora apresentada em cena; composta como um ser múltiplo, criado a partir de experiências diversas, tanto dos integrantes do iNERTE, quanto dos participantes dos encontros anteriormente organizados pelo grupo de pesquisa.

Assim como a personagem Verônica, os espectadores veem-se em contato com lances inesperados, com sensações, afetos, lembranças da própria vida, imagens de encontros com obras de arte, que surgem a partir da cena, e que não possuem necessariamente relação clara e imediata com o que foi apresentado. Ao narrar a sua experiência diante da cena assistida, o participante pode evidenciar a infinidade e a singularidade das leituras possíveis, posicionando-se como quem se organiza enquanto organiza o que fala, reconhecendo e identificando os processos internos que compõem e movimentam o ato artístico do espectador. Percebemo-nos, assim, diante de um "um observador condenado - mais do que privilegiado - a observar a si mesmo no ato da observação" (GUMBRECHT, 2010, p. 62). Por outro lado, a obra artística também se coloca como um isto problemático, pois o seu sentido não está fechado e pronto para ser desvendado: "Não se trata de um monumento a revelar monologicamente seu Ser atemporal. Ela é, antes, como uma partitura voltada para a ressonância sempre renovada de sua leitura" (JAUSS, 1994, p. 25). Isto é, as formas poéticas não são estáveis e precisas, "as formas poéticas estão numa situação de tensão, numa forma estrutural de oscilação com a dimensão do sentido" (JAUSS, 1994, p. 40). As duas condições - a do espectador capaz de se observar enquanto observa e a da instabilidade de sentidos presente na obra artística - surgem como aspectos fundamentais para o estudo de uma poética do espectador.

O desafio principal da pesquisa - assim consideramos - está no convite a que os espectadores possam, não somente atuar criativamente em sua relação com as cenas teatrais, compondo breves discursos cênicos a partir das proposições artísticas que são oferecidas, mas também refletirem acerca do sentido e da necessidade de teatro que têm (ou poderiam ter) as nossas sociedades contemporâneas. O vetor principal de nossa investigação, que se configura como desafio constante para o desenvolvimento da pesquisa, pode ser descrito a partir da seguinte questão: como o relacionamento modificado com a cena artística pode alterar a percepção acerca do próprio fazer artístico e também transformar o modo de análise da vida social? 
Ao observar o papel desempenhado pelo teatro em nossas sociedades, em relação a um espectador que, em perspectiva geral, deseja a todo custo ser entretido, divertido, podemos nos perguntar: o que pode ser realmente divertido e prazeroso nos tempos atuais? Como, em uma sociedade amplamente apoiada na espetacularidade dos eventos, em que fatos são veiculados e sentidos produzidos e transmitidos veloz e fragmentariamente, desencorajando a atitude estética do receptor, podemos nos manter ativos e criativos?

Para o desenvolvimento teórico da temática proposta, procuramos ampliar a investigação acerca de autores que possam nos trazer elementos de reflexão sobre o movimento interior do espectador ante a sua relação com o objeto artístico. Assim como sobre os vários momentos que compõem a experiência estética, a partir do confronto entre os que se colocam em cena e os que estão na sala. Nesse ponto, retomamos o estudo sobre o Seminário Livro X, de Lacan (2004) que, ao apontar a angústia como aspecto primordial da relação do espectador com o que será apresentado em cena, nos indica pertinente linha de análise acerca da experiência teatral. A angústia tomada não como uma emoção, mas como algo fundamental, primário, que não pode ser recalcado e que, em deslize, se manifesta como anunciação de que há algo incômodo e relevante, prestes a ser revelado. Tal como em um processo de análise - guardadas as devidas diferenças - o que se revela para o espectador, no momento em que se "abrem as cortinas", não são significados prontos, mas significantes prenhes de sentidos possíveis, que solicitam o esforço criativo do observador.

A cena teatral que não se compromete apenas em nos entreter faz convite cada vez mais insistente, e sempre de modo surpreendente, a uma atitude reflexiva, forçando-nos ao ato de pensar. Quando enfrentamos uma proposição artística assim constituída, podemos ser lançados em territórios diversos, pessoais e coletivos, que nos convidam a: experimentar lembranças de outros eventos, retomar situações vividas ainda não suficientemente elaboradas, produzir afetos indescritíveis, experimentar sensações inomináveis, inventar lances inexistentes, sonhar um futuro irrealizável. Percebendo-nos desfiados a relacionar fatos e sensações que parecem não se aproximar, ou produzir qualquer sentido imediato. Ou, quem sabe, sentimo-nos convidados a escrever um poema a partir da proposição poética, colocando-nos também na posição de artistas, em perspectiva horizontal na relação com os organizadores do evento.

A atitude do espectador pode ser compreendida como a de alguém que observa, seleciona, compara, inventa. Conecta o que percebe com tantas outras situações e 
objetos que notou em outros palcos, em outros espaços, em cenas diversas. Coloca-se atento e distraído ao mesmo tempo. Compõe um poema a partir do discurso cênico que lê, a partir do poema que lhe é proposto. Concebe signos construtores de sentido para o que assiste. De modo que a elaboração que faz da cena, a tradução do que lhe é apresentado, possa ser considerada tão artística quanto a cena que assiste. Participa do espetáculo ao criar possibilidades e estratégias de leitura, compreende fatos e narrativas à medida que revê e elabora passagens de sua própria história.

\section{Referências Bibliográficas}

BRITO, Ronaldo. Experiência crítica. São Paulo: Cosac Naify, 2005.

DESGRANGES, Flavio. A inversão da olhadela: alterações no ato do espectador teatral. São Paulo: Hucitec, 2012.

GUMBRECHT, Hans Ulrich. Produção de presença. Rio de Janeiro: Editora Contraponto/ PUC, 2010.

JAUSS, Hans Robert. A história da literatura como provocação à teoria literária. São Paulo : Ática, 1994.

LACAN, Jacques. Le séminaire. Livre X. L’angoisse. Paris : Ed. du Seuil, 2004.

LISPECTOR, Clarice. Onde estivestes de noite. Rio de Janeiro: Francisco Alves, 1994.

LEMINSKI, Paulo. Ensaios e anseios crípticos. Campinas: Editora UNICAMP, 2011.

SIMÕES, Giuliana. Veto ao modernismo no teatro brasileiro. São Paulo: Hucitec, 2010. 